\title{
Foreign Direct Investment Effect on Economic Growth: Evidence from Guinea Republic in West Africa
}

\author{
Keita Mohamed Lamine (corresponding author) \\ Shanghai University of Finance and Economics \\ Zhong Shan North No.1 Road, No.369, Shanghai-China, PO.BOX: 200083 \\ E-mail: molamkeita@yahoo.fr \\ Dakai Yang \\ School of Public Economics \& Administration \\ Shanghai University of Finance and Economics \\ E-mail: youngdakai@163.com
}

Received: November 17, $2010 \quad$ Accepted: November 30, $2010 \quad$ doi:10.5430/ijfr.v1n1p49

\begin{abstract}
The aim of this paper is to understand the contribution of Foreign Direct Investment on Guinea Republic's Economic growth. The Granger Causality Test is used to study the relationship between FDI and Economic Growth proxies. Our results show that the level of FDI is still low in order to promote economic growth for the Guinea Republic. Indeed, the Granger Causality Test demonstrated that the GDP can promote the level of foreign direct investment, which means that if the level of GDP increases in Guinea, FDI will also follow. Some other factors as EMPLOYMENT can promote FDI, thus the Guinean government has to play the key role of employment promotion to attract investments from abroad. In other way, we found also that school enrollment can increase the GDP and indirectly the FDI. Actually, the economic situation of Guinea has to be ameliorating by policies and regulations, which can attract and protect investors, even to attract Guinean Diaspora’s investment.
\end{abstract}

Keywords: Economic growth, FDI, Granger Causality

\section{Introduction}

The role of the foreign direct investment (FDI) has been recognized as a growth-enhancing factor in the developing countries. FDI is recognized as a catalyst for output growth, capital accumulation, and technological progress seems to be a less controversial hypothesis in theory than in practice. Campos and Kinoshita (2002) wrote: "the positive impact of foreign direct investment (FDI) on economic growth seems to have acquired status of stylized fact in the international economics literature". The effects of FDI in the host economy are normally believed to be increase in the employment, increase in productivity, and increase in exports and, of course, increased pace of transfer of technology.

Guinea is a small, underdeveloped market open to U.S. direct investment. Guinea's Investment Code of 1987 guarantees the right of all individuals or private legal entities of both Guinean and foreign nationality to undertake any economic activity in accordance with current laws and regulations. An investment promotion unit exists within the Ministry of Commerce.

Our study is structured as follows: in Section 1 we provide a review of the theoretical and empirical literature dealing with the determinants of direct foreign investment. In Section 2, we analyze the situation of FDI and several economic factors in Guinea. In section 3, we outline our model and present the results obtained. The results are then analyzed in Section 4. Lastly, we present the conclusions of our study.

\section{FDI and economic growth: literature and empirical review}

$\mathrm{Xu}$ (2000) show that FDI brings technology, which translates into higher growth only when the host country has a minimum threshold of stock of human capital. Alfaro, Chanda, Kalemli-Ozcan and Sayek (2004), Durham (2004), and Hermes and Lensink (2003) provide evidence that only countries with well-developed financial markets gain significantly from FDI in terms of their growth rates. Aitken and Harrison (1999) do not find any evidence of a 
beneficial spillover effect between foreign firms and domestic ones in Venezuela over the 1979-1989 periods. Similarly, Haddad and Harrison (1993) and Mansfield and Romeo (1980) find no positive effect of FDI on the rate of economic growth in developing countries, namely in Morocco. Blomstrom et al (1994) also showed that a positive growth-effect of FDI may be real whether the country in sufficiently rich. Carkovic and Levine (2002) rejected this finding, taking account of an interaction term from income per capita and FDI.

Graham and Krugman (1991), Kindleberger (1969), and Lipsey (2003) show that investors often fail to bring all the capital with them when they take control of a foreign company; instead, they tend to finance an important share of their investment in the local market. Mello (1999) considered that FDI affects growth through the accumulation of capital as well as by the transfer of knowledge. Keshava (2008) has shown that domestic investment is more effective than FDI in promoting growth. Andreas (2006), Ndikumana and Verick (2008) and Lumbila C2005) find that FDI has a positive significant effect on economic growth.

Further, other studies suggest that the effect of FDI on economic growth depends on whether the country has minimal level of absorptive capacity (in terms of educated workforce, institutional infrastructure and liberalized markets) that allows it to exploit FDI spillovers (Borenztein et al., 1998; Carkovic and Levine, 2002).

The benefits of FDI vary greatly across sectors. FDI in the primary sector tended to have a negative effect on growth, the relationship was positive for the manufacturing sector and ambiguous in the service sector. De Mello (1999) found that FDI had a negative growth effect in non-OECD countries, which he claimed might be due to the fact that FDI reduces total factor productivity growth.

\section{FDI economic factors in Guinea}

According to the Bureau of Economic, Energy and Business Affairs, February 2009, statistics on foreign direct investment are difficult to obtain, but regional stability, improved economic management, and external market factors increased investment over the last two years.

The Guinean Central Bank estimates that Foreign Direct Investment (FDI) in Guinea was \$125 million in 2006 and $\$ 385.9$ million in 2007. Of the 2007 total, mining sector investment accounted for $67 \%$, telecoms $25 \%$, and commercial banks seven percent. Mining giant Rio Tinto accounted for $75 \%$ of the total investment in the mining sector.

Global Alumina and the Alcoa-Rio Tinto-Alcan consortium are at the early stages of building two alumina refineries in the Boke region of Guinea. The two projects have a combined value of close to $\$ 7$ billion. In addition, Chinese and other mining companies have either signed agreements or are pursuing agreements to further develop Guinea's massive bauxite potential, but these companies are still in exploratory stages. International mineral companies, Rio Tinto and BHP Billiton have both begun work on large multi-billion dollar iron ore projects in the Forest region of southeastern Guinea. However, Rio Tinto's claim is currently in dispute after the GoG revoked its concession in 2008. (See section on Dispute Settlement.)

Two gold-mining companies, Societé de Minière de Dinguiraye (SMD) and Societe Aurifère de Guinee (SAG) are investing and expanding their businesses, though smallscale artisanal mining is also a major factor in that sector. Lebanese traders have a visible foreign business presence, with interests in real estate, small manufacturing, and wholesale and retail import and sales. Chinese enterprises are a growing factor in health care, retail trade and other small firms.

Investing in Guinea is simplified through the Office of Private Investment Promotion (OPIP), created in 1992. OPIP is a one-stop business registration office, centralizing the administrative, legal, fiscal, and other formalities required to invest in Guinea. It also doubles as the office for promotion of the African Growth and Development Act (AGOA) in Guinea. Under the late President Conte, the GoG stated that the enhanced use of AGOA by Guinean exports is a priority for the nation; however, few concrete steps were taken to actively encourage export.

\section{Data and methodology}

\subsection{Data and variables}

The sample period runs from 1985 to 2008 for the Guinea Republic. The data are drawn from the World Development Indicators published by the World Bank (2009). Guinea Republic is an interesting country for analysis because it has different history of macroeconomic experience, policy regimes and growth patterns from 1987 to2009. We choose the real per capita GDP growth to represent the economic growth. The variable foreign direct investment equals to FDI net inflows. Among the other determinants of economic growth, we choose to focus on three factors. We include employment as a percentage of total population ages 15-24. Primary School enrollment is used as a proxy for human capital development. The degree of trade openness is measured by the share of the sum of exports plus imports to GDP. 
It captures the trade policy.

\subsection{Econometric Model}

Regression Equation

$G D P=\lambda+\alpha F D I+\beta P S E+\chi E M P L O Y M E N T+\delta O P E N N E S S+\varepsilon$

\section{Granger Causality}

The granger will help us to find out the relationship between any economic growth variable, which the GDP for the case of our research and Foreign Direct Investment.

$$
\mathrm{Y}_{\mathrm{t}}=\alpha_{0}+\sum_{i=1}^{\mathrm{k}_{2}} \alpha_{\mathrm{i}} \mathrm{Y}_{\mathrm{t}-\mathrm{i}}+\sum_{i=1}^{k_{2}} \beta_{i} \mathrm{X}_{\mathrm{t}-\mathrm{i}}+\varepsilon_{\mathrm{t}}
$$

and

$$
\mathrm{X}_{\mathrm{t}}=\gamma_{0}+\sum_{t=1}^{\mathrm{k}_{2}} \gamma_{1} \mathrm{Y}_{\mathrm{t}-1}+\sum_{t=1}^{\mathrm{k}_{4}} \delta_{1} \mathrm{X}_{\mathrm{t}-1}+\varphi_{\mathrm{t}}
$$

Where $\mathrm{X}$ denotes an indicator of economic growth, $\mathrm{Y}$ denotes the FDI and the subscripts $\mathrm{t}$ and $\mathrm{t}-\mathrm{i}$ denote the current and lagged values. Hsiao (1981) suggests searching over the lag lengths (k1 to k4) and applying an information criterion to determine the optimal length of the lag structure. We will use the three most common choices of information criteria (Akaike, 1969; Hannan and Quinn, 1979; and Schwarz, 1978) to find the lag in either X or Y will be optimal.

\subsection{Empirical results}

According to our result in Table 1, we found that the level of FDI is still low in order to promote economic growth for the Guinea Republic. Researchers showed that the FDI always promote economic growth, but for the case of Guinea Republic, this assumption cannot be applied. The R-square is good which means that our regression is valid, but all the coefficient are still insignificant, thus we can conclude that in Guinea the level of FDI is not interesting and cannot affect economic growth.

After running the Granger Causality test (Table 3), we found that the GDP can promote the level of foreign direct investment, which means that if the level of GDP increases in Guinea, FDI will also follow. By the way, the Granger shows also that EMPLOYMENT can promote FDI. So the Guinean government has to play the key role of promoting employment in order to attract investment from abroad. In other way, we found also that school enrollment can increase the GDP and indirectly the FDI. This is true at all, because educated people constitute qualified workers, which promote economic development. Investors are more willing to invest in countries where it is easier to find qualified workers.

\section{Conclusions}

The objective of this study was to shed light the impact of the foreign direct investment (FDI) in developing Guinea Republic on the economic growth. In order to undertake it we performed an econometric model based in data for the 1985-2008 periods. First of all, we were able to determine that both the size of the economy, as measured by GDP is not affected by the inflows of FDI, due to the fact that since years ago, investors are very reticent on investing in Guinea.

But some variables as school enrollment, employment proved to be an important determinant of FDI, being highly significant as well. This demonstrates that a great deal of the direct investments in developing countries has been directed towards activities that are relatively knowledge-intensive, and that policies aiming at increasing the level of education may induce these investments.

The coefficient of an economy's degree of openness (OPENNESS) was included as a proxy to reflect the willingness of a country to accept foreign investment, and proved to be important in attracting capital, considering that said variable presented the expected sign, and was highly significant. Anyway, it is still not late for Guinean government to make attractive policies for foreign investors even to push Guinean from Diaspora to come back and invest in their country.

Lastly, given the fact that there is still much debate regarding the causality relation between direct investment and GDP, a causality test between FDI and GDP was performed. There was evidence of the existence of causality in GDP leading to FDI, but not vice versa. This seems to confirm the case of Guinea, for example, whose economy, which is one of the lowest developing economies in Africa caused by embargo, presenting one of the lowest rates of growth in recent years, will certainly be willing to encourage the largest recipients of foreign capital by creating a well functioning investment climate. 


\section{References}

Xu, B. (2000). Multinational Enterprises, Technology Diffusion, and Host Country Productivity Growth. Journal of Development Economics, 62, 477-493.

Alfaro, L., Chanda, A., Kalemli-Ozca, S., and Sayek,S. (2004). FDI and Economic Growth, the Role of Local Financial Markets. Journal of International Economics, 64, 113-134.

Hermes, N., and Lensink, R. (2003). Foreign Direct Investment, Financial Development and Economic Growth. Journal of Development Studies, 40, 142-163.

Graham, E., and Krugman, P. (1991). Foreign Direct Investment in the United States. Washington D.C.: Institute for International Economics.

Kindleberger, C. P. (1969). American Business Abroad. New Haven: Yale University Press.

Lipsey, R. E. (2003). Foreign Direct Investment and the Operations of Multinational Firms: Concepts, History, and Data. In E. Kwan Choi and James Harrigan (eds.) Handbook of International Trade. Oxford: Blackwell.

Aitken, B., and Harrison, A. (1999). Do Domestic Firms Benefit from Direct Foreign Investment? Evidence from Venezuela. American Economic Review, 89 (3), pp. 605-618.

Haddad, M., and Harrison, A. (1993). Are there spillovers from direct foreign investment? Journal of Development Economic, 42, pp. 51-74.

Mansfield, E., and Romeo, A. (1980). Technology Transfer to Overseas Subsidiaries by U.S.-Based Firms. Quarterly Journal of Economics, 95 (4), pp. 737-750.

Campos, N.F., and Kinoshita, Y. (2002). When is FDI good for growth? A First Look at the Experience of the Transition Economies. Working Paper.

Blomstrom, M., Lipsey, R.E., and Zejan, M. (1994). What Explains Growth in Developing countries? NBER Discussion Paper 1924.

Carkovic, M., and Levine, R. (2002). Does Foreign Direct Investment Accelerate Economic Growth? University of Minnesota. Working Paper.

MELLO, Luiz R. de. (1999) Foreign direct investment-led growth: evidence from time series and panel data. Oxford Economic Papers 51: 199-151.

Borensztein, E. J., De Gregorio, J. W., Lee, J. W. (1998). How Does FDI Affect Economic Growth? J. Inter. Econs. 45(1): 115-135.

Keshava, S. (2008). The effect of FDI on India and Chinese Economy; A comparative analysis. Second Singapore International Conference on Finance.

De Mello, L. R. (1999). Foreign Direct Investment - Led Growth: Evidence from Time Series and Panel Data, Oxford Economic Papers, 51: 133-151.

Andreas, J. (2006). The Effects of FDI Inflows on host Country Economic Growth. CESIS Electronic UK. Working Paper Series No. 58.

Ndikumana, L., Verick, S. (2008). The Linkages between FDI and Domestic Investment: Unravelling the Developmental Impact of Foreign Direct Investment in Sub - Saharan Africa. IZA Working Paper No. 3296.

Lumbila, K.N. (2005). What makes FDI Work? A Panel Analysis of the Growth Effect of FDI in Africa. Africa Region Working paper Series No. 80. 
Table 1. Regression

Dependent Variable: FDI

Method: Least Squares

Date: $09 / 02 / 10 \quad$ Time: $16: 58$

Sample (adjusted): 724

Included observations: 10 after adjustments

\begin{tabular}{lcccc}
\hline \hline \multicolumn{1}{c}{ Variable } & Coefficient & Std. Error & t-Statistic & Prob. \\
\hline \hline C & $3.72 \mathrm{E}+09$ & $1.50 \mathrm{E}+10$ & 0.248347 & 0.8137 \\
GDP & 1067548. & 4836857. & 0.220711 & 0.8340 \\
EMPLOYMENT & -59042090 & $1.78 \mathrm{E}+08$ & -0.332343 & 0.7531 \\
\multicolumn{1}{c}{ PSE } & -1233387. & 5229446. & -0.235854 & 0.8229 \\
\multicolumn{1}{c}{ OPENNESS } & 85.45341 & 43.91810 & 1.945745 & 0.1093 \\
\hline \hline R-squared & 0.920212 & Mean dependent var & 99135643 \\
Adjusted R-squared & 0.856381 & S.D. dependent var & $1.52 \mathrm{E}+08$ \\
S.E. of regression & 57783903 & Akaike info criterion & 38.88917 \\
Sum squared resid & $1.67 \mathrm{E}+16$ & Schwarz criterion & 39.04046 \\
Log likelihood & -189.4459 & Hannan-Quinn criter. & 38.72320 \\
F-statistic & 14.41643 & Durbin-Watson stat & 2.719903 \\
Prob(F-statistic) & 0.005935 & & \\
\hline \hline
\end{tabular}

Table 2. Descriptive statistics

\begin{tabular}{|l|c|c|c|c|c|}
\hline & FDI & GDP & EMPLOYMENT & PSE & OPENNESS \\
\hline Mean & 17.15217 & 5.925639 & 4.308190 & 4.146511 & 5330628. \\
\hline Median & 17.47316 & 5.926226 & 4.309456 & 4.147010 & 4711471. \\
\hline Maximum & 19.77109 & 6.016619 & 4.324133 & 4.498753 & 7946648. \\
\hline Minimum & 13.55285 & 5.814230 & 4.287716 & 3.575118 & 4290838. \\
\hline Std. Dev. & 2.164619 & 0.069810 & 0.012611 & 0.298356 & 1279538. \\
\hline Skewness & -0.428620 & -0.485846 & -0.439636 & -0.584431 & 1.173923 \\
\hline Kurtosis & 2.095386 & 2.136427 & 2.152009 & 2.521707 & 2.937745 \\
\hline & & & & & \\
\hline Jarque-Bera & 0.582446 & 0.633729 & 0.559578 & 0.598126 & 2.068596 \\
\hline Probability & 0.747349 & 0.728430 & 0.755943 & 0.741513 & 0.355476 \\
\hline & & & & & \\
\hline Sum & 154.3696 & 53.33075 & 38.77371 & 37.31859 & 47975653 \\
\hline Sum Sq. Dev. & 37.48462 & 0.038987 & 0.001272 & 0.712128 & $1.31 \mathrm{E}+13$ \\
\hline & & & & & 9 \\
\hline Observations & 9 & 9 & 9 & & 9 \\
\hline
\end{tabular}


Table 3. Granger Causality Test

Pairwise Granger Causality Tests

Date: 10/23/10 Time: 14:05

Sample: 124

Lags: 1

\begin{tabular}{|c|c|c|c|}
\hline Null Hypothesis: & Obs & F-Statistic & Prob. \\
\hline GDP does not Granger Cause FDI & 21 & 3.08083 & 0.0962 \\
\hline FDI does not Granger Cause GDP & & 0.65616 & 0.4285 \\
\hline EMPLOYMENT does not Granger Cause FDI & 15 & 5.93479 & 0.0314 \\
\hline FDI does not Granger Cause EMPLOYMENT & & 0.51845 & 0.4853 \\
\hline PSE does not Granger Cause FDI & 8 & 0.63813 & 0.4606 \\
\hline FDI does not Granger Cause PSE & & 20.5454 & 0.0062 \\
\hline OPENNESS does not Granger Cause FDI & 18 & 0.42274 & 0.5254 \\
\hline FDI does not Granger Cause OPENNESS & & 0.44232 & 0.5161 \\
\hline EMPLOYMENT does not Granger Cause GDP & 17 & 0.00471 & 0.9462 \\
\hline GDP does not Granger Cause EMPLOYMENT & & 5.85456 & 0.0297 \\
\hline PSE does not Granger Cause GDP & 10 & 50.9572 & 0.0002 \\
\hline GDP does not Granger Cause PSE & & 2.12237 & 0.1885 \\
\hline OPENNESS does not Granger Cause GDP & 19 & 0.45564 & 0.5093 \\
\hline GDP does not Granger Cause OPENNESS & & 0.19456 & 0.6651 \\
\hline PSE does not Granger Cause EMPLOYMENT & 9 & 0.02034 & 0.8913 \\
\hline EMPLOYMENT does not Granger Cause PSE & & 0.02443 & 0.8809 \\
\hline OPENNESS does not Granger Cause EMPLOYMENT & 14 & 2.76645 & 0.1245 \\
\hline EMPLOYMENT does not Granger Cause OPENNESS & & 3.62191 & 0.0835 \\
\hline OPENNESS does not Granger Cause PSE & 7 & 1.57737 & 0.2775 \\
\hline PSE does not Granger Cause OPENNESS & & 0.00078 & 0.9791 \\
\hline
\end{tabular}

